\title{
EVALUATION OF EFFECTS OF AGRICULTURAL INSURANCE SCHEME ON AGRICULTURAL PRODUCTION IN ONDO STATE
}

\author{
Akinrinola Olumide O., Okunola Akinbode M., Researchers \\ Federal University of Technology, Akure, Nigeria \\ E-mail: akinrinolaolu@gmail.com, okunolaakinbode@gmail.com
}

\begin{abstract}
This study was carried out to see how well the objectives of the Nigerian Agricultural Insurance Scheme had been achieved in Ondo State. Multi-stage sampling technique was used to select 120 insured farmers from two local government areas and a well-structured questionnaire was used to collect data from the farmers. The data collected were analyzed using descriptive statistics. The analysis shows that accessibility to credit was the only reason the farmers participated in the insurance scheme. However, the farmers affirmed that there was increase in investments which brought about increases in their output. Thus, their accessibility to farm credit could be said to be responsible for these increases. Hence, some of the objectives of the agricultural insurance scheme to increase agricultural production and accessibility to credit had been achieved.
\end{abstract}

\section{KEY WORDS}

Agricultural Insurance; Farm Credit; Investment; Output; Accessibility; NAIC.

In the business of agricultural production and marketing, risk is an unavoidable but manageable element. Agricultural production can vary widely from year to year due to unforeseen weather, disease/pest infestation, and/or market conditions causing wide swings in yields and commodity prices. The wide swings in yields and output prices generate high variability in farmer household income. The uncertainty in future incomes complicates both short-term production and long-term planning, that is whether to expand or reduce production, whether to invest in acquisition fixed and moveable assets, whether to stay in farming or to exit.

Farming communities face a variety of risks. Although they have learned to live with these risks by employing various devices to prevent, avoid, mitigate or cope with them, there are still the problems of residual risks. These are the catastrophic types that human intervention can neither prevent nor mitigate. The damage they cause to lives and properties cannot be underestimated. In such situations, agricultural insurance may prove useful.

Because of risks inherent in agricultural production which lead to farm income uncertainty and low or no profit, many farmers express fears on their ability to meet overhead costs, family needs, and also repay any debt. On the other hand, formal lending institutions also express apprehension on farmers' ability to repay loans. These lenders seek to reduce the possibility of poor loan recovery by reducing amount of loan to agriculture and in some cases seek collateral from the farmers before granting a loan. This has led governments all over the world to intervene with a range of risk management programmes for farmers thereby enhancing their credit worthiness before lending institutions (Hazell, 1992).

Peasant farmers are naturally keen to avoid taking risks which might threaten their livelihood and is often reflected in their farming practices (Alli, 1980). Notionally, there is a trade-off between the levels of risk that farmers can withstand and the aggregate level of food production in the country (Ray, 1985). Recognition of this trade-off by policy makers has led to the introduction of programmes that attempt to address peasant farmers' aversion to risk (Alli, 1980). One such approach is to establish a scheme to offer insurance against agricultural risks. The introduction of agricultural insurance has therefore continued to generate a keen interest among academics and politicians because of the volume of investment involved (Olubiyo, 2009).

Agricultural Insurance, in its widest sense may be defined as the stabilization of income, employment, price and supplies of agricultural products by means of regular and deliberate savings and accumulation of funds in small installments by many in favourable 
time periods to defend some or few of the participants in bad time periods (Arene, 2005). The term "insurance" is simply "a risk management strategy". The primary motive of any agricultural insurance policy is to serve as a security for losses resulting from natural disasters. It also serves as collateral for agricultural loan to the farmers from banks. (Arene, 2005).

In Econometric Analysis of the Impact of Agricultural Insurance on Farming Systems in the Middle Belt, Nigeria (Olubiyo et al, 2009), it is found that one of the underlying assumptions of the agricultural insurance scheme was that its introduction would encourage farmers to positively change their farming practices. Specifically NAIC was established for farmers to have more access to essential farm resources that would motivate them to embrace the use of modern farming practices with the assumption that such practices will lead to increase the quality and quantity of farm production and food supplies to the market. The study discovered that NAIC exerts influence on the range of inputs and production methods farmers used on the farm.

Patrick (2010), in his study on the Response of Poultry Farmers to Agricultural Insurance in Delta State, Nigeria discovered that the respondent farmers agree to the following statements: agricultural enterprise is faced with risks and uncertainties; agricultural insurance is beneficial; agricultural insurance reduces farmers' worries and stress. The fact that the respondents in his study recognized the fact that agricultural insurance is beneficial and that it can help to reduce farmers' worries and stress over uncertainties associated with agricultural enterprise, it then implies that the respondents had a favorable attitude towards agricultural insurance. He further found that farmers recognized the fact that poultry enterprise being an agricultural activity is faced with risks and uncertainties, and that one way to overcome such risks and uncertainties is through insurance cover.

Jafiya and Toro (1998) stated that NAIS is linked to Agricultural Credit Guarantee Fund Scheme (ACGFS) operated by the CBN, and to the agricultural loan scheme from the public sources. The linkage makes it mandatory to farmers obtaining such loans to insure their farms under the NAIS. The NAIS and ACGFS are complimentary or mutually reinforcing each other. The ACGFS guarantees bank against loan defaulters and not farmers whereas under the NAIC scheme, farmers are protected against losses resulting from natural hazards NAIC does not give banks guarantee of loan payment in the event of defaults unrelated to natural hazard which the ACGFS does.

Aina and Omonona (2012), in their review of the Nigerian Agricultural Insurance Scheme: Prospect, Achievement and Problems, observed that with regards to achievements, the Nigerian Agricultural Insurance Cooperation (NAIC) premium income for 1989-1993 was

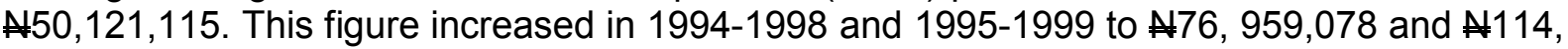
049,706 respectively (WAICA, 2000). The figure increased in 2000-2004 and 2005-2009.

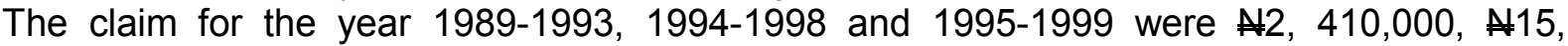
662,236 and $\$ 35,197,000$ respectively. This persistent increase in the premium income showed that more farmers are being aware of the insurance scheme and are keying into it.

The National Agricultural Extension and Research Liaison Services (NAERLS 1991) identified the following as the benefits of agricultural insurance to farmers:

(a) it protects farmers against financial disaster after suffering any of the insured risks for which indemnity (compensation) is paid. The farmer is not only able to continue in business but also the stability of his income is enhanced;

(b) agricultural insurance empowers the farmers to obtain farm credit. Since insurance guarantees protection against crop and/or livestock failure, the insured farmer has greater confidence in obtaining loans;

(c) it facilitates better planning and project implementation since there is a high level assurance for continuity in business;

(d) it serves as an assurance to banks and other financial institutions who grant loan for agricultural purposes as loans given will be repaid;

(e) it build farmers confidence in using new technologies and making greater investments in agriculture Recognizing the benefits of agricultural insurance, the Nigerian Government in 1987 established the Nigerian Agricultural Insurance Scheme (NAIS). 
Historical Setting of Nigerian Agricultural Insurance Corporation. In the 1985 budget, $20 \%$ of the 1.06 billion naira total capital allocation went to agriculture. To tie down this bogus allocation to agriculture, the government introduced an agriculture insurance scheme.

The Nigerian Agricultural Insurance Company (NAIC) was established on the $15^{\text {th }}$ of December, 1987. It was made a Corporation on the $1^{\text {st }}$ of June, 1993. The Nigerian Agricultural Insurance Scheme has been designed to benefit the small, medium and largescale farmers, either in groups or as individual producers.

Objectives of the Scheme. The broad objective of the Nigerian Agricultural Insurance Scheme (NAIS) is to offer protection to the farmer from the effects of natural disasters and to ensure payment of appropriate compensation sufficient to keep the farmer in business after suffering loss.

The Scheme is designed specifically to: promote agricultural production since it would enhance greater confidence in adopting new and improved farming practices and in making greater investment in the agricultural sector on the Nigerian economy, thereby increasing the total production; provide financial support to farmers in the event of losses arising from natural disasters; increase the flow of agricultural credit from lending institutions to the farmers; minimize or eliminate the need for emergency assistance provided by Government during period of agricultural disasters.

Objectives of the Study. Thus the general objective of this study is to evaluate the effects of agricultural insurance scheme on agricultural production in Ondo State.

The specific objectives of this study are to: examine the socio-economic factors of the respondents; examine the reasons for farmers' participation in the insurance scheme; examine the effect of the insurance scheme on farm investment; examine the effect of the insurance scheme on accessibility of farmers to credits.

\section{METHODOLOGY}

Study Area. The study was carried out in Ondo State, Nigeria. The State is made up of 18 local government areas. It State lies in the rainforest zone of Nigeria with $80 \%$ of the inhabitants to engaged in Agriculture. The climate of the state is tropical with two distinct seasons: the raining season which usually occur between April and October and the dry season that usually start from November to March.

Sampling Technique. Multi-stage sampling technique was used for this study. Two local government areas were chosen purposively base on the prevalence of the insured farmers in these areas. A total of one hundred and twenty, (120) farmers were used as respondents. Sixty insured famers were randomly selected from the records of the Nigerian Agricultural Insurance Corporation from each of the two local government areas.

Data Collection. Mainly primary data were used for this study. The primary data were collected through a well-structured questionnaire.

Method of Data Analysis. Data collected were analysed using both descriptive statistic. Descriptive statistic was used to analyse the effect of the participation of insured farmers on their farm investments, farm sizes and their accessibility to farm credits.

\section{RESULTS AND DISCUSSIONS}

Socio-Economic Distributions of the Farmers. The result in table 1 shows that all the insured farmers are over 30 years with age range of $41-50$ accounting for $50 \%$ of the age distribution. Thus, the involvement of youths in agricultural production in the study area is very low.

The gender distribution (see table 1) of the farmers is asymmetrical with male farmers been about $63 \%$ and females, about $37 \%$. This however shows that male farmers take more risks than the female farmers and hence indicates that they are more informed on how to manage their vulnerability to loss by participating in the insurance scheme.

The result (see table 1) shows that all the farmers are married. The need for the farmers to meet their responsibilities as married people by ensuring maximum output may be 
responsible for their engagement in full scale agricultural production which has necessitated their participation in the insurance scheme in a bid to minimize their exposure to imminent losses.

Table 1 - Distribution of the Socio-economic Characteristics of the Respondents

\begin{tabular}{|c|c|c|}
\hline Variable & Frequency & Percentage (\%) \\
\hline $\begin{array}{c}\text { Age } \\
\text { Less than } 21 \\
21-30 \\
31-40 \\
41-50 \\
\text { Above 50 } \\
\text { Total }\end{array}$ & $\begin{array}{l}0 \\
0 \\
20 \\
60 \\
40 \\
120\end{array}$ & $\begin{array}{c}0 \\
0 \\
16.7 \\
50.0 \\
33.3 \\
100.0\end{array}$ \\
\hline $\begin{array}{c}\text { Gender } \\
\text { Male } \\
\text { Female } \\
\text { Total } \\
\end{array}$ & $\begin{array}{c}44 \\
76 \\
120 \\
\end{array}$ & $\begin{array}{c}36.7 \\
63.3 \\
100.0 \\
\end{array}$ \\
\hline $\begin{array}{c}\text { Marital Status } \\
\text { Divorced } \\
\text { Single } \\
\text { Married } \\
\text { Widow } \\
\text { Total }\end{array}$ & $\begin{array}{c}0 \\
0 \\
120 \\
0 \\
120\end{array}$ & $\begin{array}{c}0 \\
0 \\
100.0 \\
0 \\
100.0\end{array}$ \\
\hline $\begin{array}{l}\text { Educational Level } \\
\text { No formal Education } \\
\text { Adult Education } \\
\text { Primary Education } \\
\text { Secondary Education } \\
\text { Tertiary Education } \\
\text { Total } \\
\end{array}$ & $\begin{array}{c}0 \\
0 \\
0 \\
52 \\
68 \\
120 \\
\end{array}$ & $\begin{array}{c}0 \\
0 \\
0 \\
43.3 \\
56.7 \\
100.0 \\
\end{array}$ \\
\hline $\begin{array}{c}\text { Farming System } \\
\text { Commercial } \\
\text { Peasant } \\
\text { Total }\end{array}$ & $\begin{array}{c}120 \\
0 \\
120 \\
\end{array}$ & $\begin{array}{c}100.0 \\
0 \\
100.0\end{array}$ \\
\hline $\begin{array}{c}\text { Farming Experience } \\
\text { Less than } 10 \\
10-20 \\
21-30 \\
31-40 \\
41-50 \\
\text { Above } 50 \\
\text { Total } \\
\end{array}$ & $\begin{array}{c}48 \\
44 \\
24 \\
0 \\
0 \\
4 \\
120\end{array}$ & $\begin{array}{c}40.0 \\
36.7 \\
20.0 \\
0 \\
0 \\
3.3 \\
100.0 \\
\end{array}$ \\
\hline
\end{tabular}

Source: Field Survey, 2013

Table 2 - Reason for Participating in the Scheme

\begin{tabular}{|c|c|c|}
\hline Reason & Frequency & Percentage \\
\hline Accessibility to loan & 120 & 100 \\
Aversion to Risk & 0 & 0 \\
Insurance Marketing & 0 & 0 \\
\hline Total & 120 & 100 \\
\hline
\end{tabular}

Source: Field Survey, 2013

Table 3 - Farm Investment of Insured Farmers after Participation

\begin{tabular}{|c|c|c|}
\hline Increase in Investment & Frequency & Percentage \\
\hline Yes & 120 & 100 \\
No & 0 & 0 \\
\hline Total & 120 & 100 \\
\hline
\end{tabular}

Source: Field Survey, 2013

Table 4: Farm Output after Participation in the Scheme

\begin{tabular}{|c|c|c|}
\hline Increase in Farm Size & Frequency & Percentage \\
\hline Yes & 120 & 100 \\
No & 0 & 0 \\
\hline Total & 120 & 100 \\
\hline
\end{tabular}

Source: Field Survey, 2013 
The result in table 1 shows that about $43 \%$ of the farmers have secondary education while about $57 \%$ possess tertiary education. The distribution shows that the level of education of the farmers may have influenced their level of awareness as to how to minimize the effects of agricultural risks or in case of its occurrence, cover the costs. However, the result (see table 1) shows that all the farmers are involved in commercial agriculture.

From the result (see table 1), $40 \%$ of the farmers have less than 10 years farming experience, with about $37 \%$ and $20 \%$ having $10-20$ years and $21-30$ years farming experience respectively and about $3 \%$ having over 50 years farming experience.

Reason for Participation in the Scheme. All of the insured farmers (see table 2) participated in the insurance scheme because is it one of the requirements needed to access agricultural loans. Thus, this indicates that the objectives of the Nigerian Agricultural Insurance Scheme to increase access of farmers to credits is been achieved.

Effects of the Scheme on Agricultural Production. All of the farmers (see table 3) confirmed that there has been increase in their investments after their participation in the scheme. However, this may not be unconnected from the fact that they all participated in the scheme in order to access agricultural loans and these loans have increase their input consumption level.

All of the insured farmers (see table 4) confirmed that their outputs have increased since their participation in the insurance scheme. This is as a result of the increase in their scale of production and input consumption which cannot be unconnected from their access to credit which brought about increased investment in their production.

\section{CONCLUSION}

The findings of this study showed that there was increase in the investment level of the farmers after their participation in the insurance scheme. This can be attributed to their accessibility to farm credits which is one of the objectives of the insurance scheme. The farmers also increased their farm sizes which can be related to their increased input consumption power ensured by the access to credits which also brought about increase in output. This indicates that objectives of the agricultural insurance scheme are been achieved.

The Nigeria Agricultural Insurance Corporation should however ensure that farmers are aware of the benefits of participation in the scheme so that they will on their own take insurance cover and not because it is a prerequisite for loan accessibility. The Corporation must improve on its insurance marketing to get the farmers to know about the scheme.

The farmers need to be aware of the security the insurance scheme offers them when and if they adopt new technology which in actual sense will bring about increase in yield at minimum cost. Hence, though the farmers may have access to farm credits, the yield if improved technologies are used will be higher and will pay for the interest on the loans.

\section{REFERENCES}

1. Aina, O.S, Omonona B.T(2012).Nigeria Agricultural Insurance Scheme (NAIS): Prospect, Achievement and Problems. Global Advanced Research Journal of Agricultural Science 1(5): $97-103$.

2. Alli, K.M.(1980). Agricultural Administration 7(2): 97-106.

3. Arene, C.J, D.M. Tee (2005). Agricultural Insurance in Humid Nigeria: An Analysis of the Performance of the Livestock livestock subsector. Revista di Agricultura Tropicale e subtropicale, 90 (2): 165-176.

4. Hazell, P.B.R.(1992). The Appropriate Role of Agricultural Insurance in Developing Countries. Journal of International Development. Vol.4. 567-581.

5. Jafiya I.A, Toro B.L. (1998). Essential features of the Nigeria Agricultural Insurance schemes. Workshop proceeding on; The Role of Financial Institution in the Operations of the Nigeria Agricultural Insurance Scheme. 
6. NAERLS (1991). Practices of Agricultural Insurance in Nigeria. Extension Bulletin. No. 10, Abuja, Nigeria.

7. Olubiyo S.O. et al(2009): Econometric Analysis of the Impact of Agricultural Insurance on Farming Systems in the Middle Belt, Nigeria. African Journal of Food, Agriculture, Nutrition and Development 9 (6): 7-9.

8. Patrick, C.A.(2010). Poultry Farmers' Response to Agricultural Insurance in Delta State, Nigeria. J. Agri. Sci. 1(1): 43-47.

9. Ray, P.K. (1985). Agricultural Insurance, theory and practice and Application to Developing Countries 2nd ed. Oxford Pergaman Press. 